\title{
HEAD LICE IN HAIR SAMPLES FROM YOUTHS, ADULTS AND THE ELDERLY IN MANAUS, AMAZONAS STATE, BRAZIL
}

\author{
Suellen Cristina Barbosa NUNES(1), Raquel Borges MORONI(2), Júlio MENDES(3), Sílvia Cássia Brandão JUSTINIANO(4) \& Fábio Tonissi MORONI(5)
}

\begin{abstract}
SUMMARY
A study of head lice infestations among young people, adults and elderly individuals was conducted from August 2010 to July 2013 in Manaus, AM, Northern Brazil. Hair samples collected from 1,860 individuals in 18 barber shops and beauty parlors were examined for the ectoparasite. The occurrence of pediculosis and its association with factors, such as sex, age, ethnicity, hair characteristics and the socioeconomic profile of salon customers, salon location and seasonal variation were determined. The overall occurrence rate was $2.84 \%$. Occurrence was higher in hair samples from non-blacks and the elderly. Higher occurrence was also observed during kindergarten, elementary and junior education school holidays. The results indicate that the occurrence of head lice among young people, adults and the elderly in Manaus is relatively low compared to that determined in children and in other regions of the country. After children, the elderly were the most affected. The study also indicated the need to adopt additional procedures to improve surveys among the population with low or no purchasing power, which is usually the most affected by this ectoparasitic disease.
\end{abstract}

KEYWORDS: Head lice; Hair samples; Pediculus capitis; Epidemiology; Manaus.

\section{INTRODUCTION}

Pediculosis, infestation by Pediculus capitis De Geer (head lice), has worldwide distribution, including Brazil ${ }^{11}$, and is observed in all age groups, though particularly among children ${ }^{4,23,28}$. It is considered one of several ectoparasites neglected by the scientific community and healthcare authorities ${ }^{12}$.

Infestation is characterized by intense itching, secondary infection and anemia in cases of severe infestation and inadequate $\operatorname{diet}^{23}$. Severe infestations are associated with low socioeconomic status, hair characteristics, parasite resistance to insecticides, genetic factors, and cultural habits ${ }^{6,8,10,24}$.

Besides the physical symptoms described above, it can cause embarrassment among children. Certain population groups, particularly adults, often resist having their heads examined for the diagnosis of the parasite, which is a fairly sensitive diagnostic method $^{3,16}$. Given this restriction, researchers have sought alternative methods of assessment regarding the degree of importance of this disease in certain populations. Analysis of samples of hair cut in salons and similar establishments is one such technique $\mathrm{e}^{7,9,16,18}$. Although it does not present the same sensitivity as direct scalp examination ${ }^{3}$, it is an alternative that permits verification of the epidemiological aspects of this parasitosis in population groups that have such restrictions.
In Brazil, epidemiological studies concerning this ectoparasitosis are concentrated in the southeastern region, while information from the northern and northeastern regions regarding infestation remains scarce $^{1,4,13}$, except for a recent study involving school-age children in urban areas of Manaus ${ }^{4}$ and another one from the state of Acre concerning infant dermatitis, which included head lice ${ }^{1}$.

Epidemiological features associated with head lice infestation among young people and adults were studied using analysis of hair cut in salons and similar establishments, located within the urban area of Manaus ${ }^{1,13}$. This study provided information concerning the occurrence, its monthly distribution and possible associations of several factors which, according to the literature ${ }^{3,4}$, can influence its occurrence, such as hair characteristics, ethnicity, age, socioeconomic status, the location of sampling, and seasonal variation.

\section{MATERIAL AND METHODS}

Manaus, in the Amazonas State, occupies an area of 11,401,092 km² $\left(4,401,986 \mathrm{~m}^{2}\right)$ and is located at $60^{\circ} 01^{\prime} 30^{\prime \prime} \mathrm{W}$ and $03^{\circ} 06^{\prime} 07^{\prime \prime} \mathrm{S}$. The city has $1,982,179$ inhabitants and is divided into six administrative zones comprising 63 neighborhoods ${ }^{15}$. The study was conducted by obtaining and examining hair samples from customers of 18 beauty parlors and barber shops located in five of the six administrative zones of this city. The criteria for choosing the establishments investigated were: random

(1) PPGIBA/Universidade Federal do Amazonas, Manaus, Amazonas, Brazil.

$(2,3)$ ICBIM/Universidade Federal de Uberlândia, Minas Gerais, Brazil.

(4) Pesquisa e Pós-graduação, Universidade Nilton Lins, Manaus, Amazonas, Brazil.

(5) ICB/Universidade Federal do Amazonas, Manaus, Amazonas, Brazil.

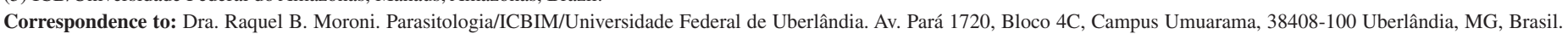

E-mail: borgesraquel@hotmail.com 
NUNES, S.C.B.; MORONI, R.B.; MENDES, J.; JUSTINIANO, S.C.B. \& MORONI, F.T - Head lice in hair samples from youths, adults and the elderly in Manaus, Amazonas State, Brazil. Rev. Inst. Med. Trop. S. Paulo, 57(3): 239-44, 2015.

selection, their location according to zone and the acceptance of their owners/managers for inclusion in the study. Two to four establishments were sampled in each administrative zone. Each establishment was visited around 15 times, with each visit on a different day to obtain hair samples, between August 2010 and July 2013. Customers who attended the establishments and appeared to be between 15 and 65 years of age were included in the study.

The owners or managers of the institutions signed a term of free and informed consent. Details on the ethical procedures adopted are described in the project approved by the Research Ethics Committee of the Federal University of Amazonas, under protocol no. CAAE 0099.0.115.000-09.

Hair samples were collected after each hair cut and individually placed in properly labeled plastic bags. Information concerning their origin and the physical appearance of the customers was recorded on a form. The samples were sent to the laboratory and analyzed with a magnifying glass and microscope to check the condition and characteristics of the hair ${ }^{18}$ (size, type, color, and thickness). Samples considered positive were those on which any of the developmental stages of lice (eggs, nymphs or adults) were identified, irrespective of whether they were viable at the time of examination.

Hair characteristics were determined according to BORGES \& MENDES ${ }^{2}$, following training with their method prior to evaluation. The hair samples were classified according to the following characteristics: length, color and thickness. Hair of up to $3 \mathrm{~cm}$ in length was considered short, medium length was from 3 to $10 \mathrm{~cm}$, and long was over $10 \mathrm{~cm}$, according to the parameters stipulated by ${ }^{19}$. Hair color was grouped into four categories: light (blonde and red), dark (brown and black), gray, and dyed. Regarding thickness, there were two categories: thin and thick ${ }^{2}$.

The ethnicity, sex and age group of the clients whose hair was sampled were determined based on observations regarding the physical appearance of the individuals during their haircuts. Regarding ethnicity, the individuals were divided into blacks and non-blacks. Age group was established according to $\mathrm{WHO}^{30}$ : young people, those who appeared to be 15-29 years old; adults, 30-59 years old; and elderly, those over 60 years old ${ }^{2}$.

The socioeconomic profile of the clients was inferred according to the value of the haircuts charged by the establishments. Thus, customers who sought a haircut in an establishment that charged $\mathrm{R} \$ 5.00$ to $\mathrm{R} \$$ 10.00 were considered to be of low socioeconomic status, $\mathrm{R} \$ 15.00$ of medium status and \$ 20.00 to $\mathrm{R} \$ 30.00$ of high status.

The monthly distribution of infestation was monitored for three years. School age children seemed to act as reservoirs of this disease ${ }^{4}$ and studies have demonstrated that significant variation in occurrence appears among children between the academic and vacation periods in Minas Gerais ${ }^{3,20}$.

Thus, this work also investigated whether there was any relation between infestations in children and individuals of other age groups by comparing prevalence rates obtained in these two periods of the year, i.e. the occurrence determined during months that composed the academic periods of kindergarten, elementary and junior education and the months these children were on vacation.

The $\chi^{2}$ statistical test was used to compare two or more proportions. In cases where significant differences between more than two proportions were observed, the data were submitted to angular transformation ( $p^{\prime}=$ arc. sen $\bigvee^{p}$ '), followed by multiple comparisons using the Tukey range test ${ }^{4,29}$. A $5 \%$ level of significance was adopted ${ }^{29}$. Confidence intervals $(95 \%)$ were also calculated for the occurrence and prevalence ratios determined.

\section{RESULTS}

An occurrence of $2.84 \%$ was detected for the 1,860 hair samples obtained from the 18 establishments surveyed. The highest occurrence rates were found in the south-central $(3.5 \%)$ and west-central areas $(3.47 \%)$. However, the differences between these rates and those obtained for other areas, where the rates were lower, were not significant $\left(\chi_{0.05}^{2}, 4=1.67, p>0.75\right)$ (Table 1).

Of the 53 positive samples, 37 had non-viable lice eggs, three had adult lice and 13 had viable eggs.

In general, the hair characteristics, length, color and thickness, did not significantly influence the prevalence rates obtained (Table 3 ). However, ethnicity and age had a significant influence on distribution,

Table 1

Occurrence of head lice among clients of barber shops and beauty parlors according to their location in the different zones of the city of Manaus, Amazonas State, Brazil

\begin{tabular}{|c|c|c|c|c|c|}
\hline Establishments & Location & $\begin{array}{l}\text { No. of samples } \\
\text { examined }\end{array}$ & $\begin{array}{l}\text { No. of samples } \\
\text { positives }\end{array}$ & $\begin{array}{c}\text { Occurrence rate }(\%) \\
95 \% \text { confidence interval }\end{array}$ & $\begin{array}{l}\text { Prevalence ratio } \\
\text { 95\% confidence interval }\end{array}$ \\
\hline I to IV & South zone & 400 & 9 & $2.25(0.8-3.7) \mathrm{A}^{\mathrm{a}}$ & - \\
\hline V to VIII & East zone & 400 & 10 & $2.5(1.22-4.03) \mathrm{A}$ & $1.1(0.73-1.64)$ \\
\hline IX to XII & North zone & 400 & 11 & $2.75(1.15-4.35) \mathrm{A}$ & $1.22(0.51-2.88)$ \\
\hline XIII to XVI & West-central zone & 460 & 16 & $3.47(1.8-5.14) \mathrm{A}$ & $1.54(0.68-3.45)$ \\
\hline XVII and XVIII & South-central zone & 200 & 7 & $3.5(0.96-6.04) \mathrm{A}$ & $1.55(0.58-4.11)$ \\
\hline Total & - & 1860 & 53 & - & - \\
\hline
\end{tabular}

${ }^{a}=$ occurrence rates with different letters are statistically different from each other by the Tukey test at a $5 \%$ level of significance. 
such that non-black individuals and the elderly had higher occurrence rates $\left(\chi_{0.05}^{2}, 1=5.05, p=0.025 ; \chi_{0.05}^{2}, 2=7.65, p<0.025\right)$ (Table 2$)$. The socioeconomic profiles of the clients, inferred from the price of a haircut charged by the establishment, did not significantly influence the rate of head lice infestation either $\left(\chi_{0.05}^{2}, 2=2.16, p>0.25\right)$ (Table 2).

Analysis of the monthly distribution of the occurrence rates revealed that the highest rate was obtained in July, a school holiday period (Fig. 1). The rates obtained for the months that composed the academic periods and the months that composed the school holiday period of school-age children were grouped and compared; the rate determined for the holiday period was significantly higher $\left(\chi_{0.05}^{2}, 1=13.28, p<0.01\right)$ (Table 2$)$.

\section{DISCUSSION}

The use of hair samples collected from barbershops for estimating the prevalence of pediculosis capitis was adopted for the first time in Brazil by ${ }^{18}$. The overall prevalence of head lice infestation in this study was relatively low, compared with other studies conducted in the state of Minas Gerais using this same technique ${ }^{3}$. However, the data obtained corroborate the results of recent research among school children in Manaus using the head inspection technique ${ }^{4}$, in which an occurrence rate of $18 \%$ was obtained in children, a rate that is also considered low for this age group compared with studies conducted in other regions of the country ${ }^{13,23}$.
The results gathered here, together with those obtained for school children in the same city $^{4}$, reflect the degree of importance of this ectoparasitosis for the population. However, it should be noted that given the lower sensitivity of this technique in relation to direct scalp examination, the real rate of occurrence of the study population is likely to be greater than that found. The differences in sensitivity are partly due to factors like the length of the hair that is $\operatorname{cut}^{18}$ and the number of people aware that they have head lice, who would not choose to cut their hair in such establishments. An additional limitation of this study is the fact that the establishments were not sampled every month of the year. Another fact that influences the monthly head lice distribution is that part of the inactive infestation results from active infestations acquired in the months prior to those in which the hair samples were obtained. However, considering that numerous establishments were sampled throughout the study period, the data obtained over the months were grouped into the academic and vacation periods of the year, while the number of hair samples obtained were satisfactory from a statistical point of view; possible bias resulting from this sampling procedure does not significantly influence the statistical analysis.

It is also worth highlighting, particularly in this study, that the portion of the general population having a less favorable socioeconomic profile may not be able to easily afford a haircut, and thus this population group may not have been adequately sampled. The fact that no significant differences were observed in comparisons between the occurrence

Table 2

Occurrence of head lice among several groups of clients of barber shops and beauty parlors, in the city of Manaus, Amazonas State, Brazil

\begin{tabular}{|c|c|c|c|c|}
\hline & No. of samples examined & No. of samples positives & $\begin{array}{c}\text { Occurrence rate }(\%) \\
95 \% \text { confidence interval }\end{array}$ & $\begin{array}{l}\text { Prevalence ratio } \\
95 \% \text { confidence interval }\end{array}$ \\
\hline \multicolumn{5}{|l|}{ Sex } \\
\hline Male & 1433 & 39 & $2.72(2.22-3.8) \mathrm{A}$ & - \\
\hline Female & 465 & 14 & $3.01(2.46-2.98) \mathrm{A}$ & $1.10(0.59-2.05)$ \\
\hline \multicolumn{5}{|l|}{ Ethnicity } \\
\hline Black & 656 & 11 & $1.67(0.69-2.65) \mathrm{A}^{\mathrm{a}}$ & - \\
\hline Non-black & 1204 & 42 & $3.48(2.45-4.51) \mathrm{B}$ & $2.08(1.07-4.01)$ \\
\hline \multicolumn{5}{|l|}{ Age group } \\
\hline Youth & 652 & 24 & $3.68(2.24-5.12) \mathrm{B}$ & $1.93(1.06-3.50)$ \\
\hline Adult & 998 & 19 & $1.90(1.06-2.74) \mathrm{B}$ & - \\
\hline Elderly & 210 & 10 & $4.76(1.89-7.63) \mathrm{A}^{\mathrm{a}}$ & $2.50(1.18-5.30)$ \\
\hline \multicolumn{5}{|c|}{ Socioeconomic profile $^{b}$} \\
\hline Low & 730 & 20 & $2.73(1.56-3.9) \mathrm{A}$ & - \\
\hline Medium & 400 & 13 & $3.25(1.52-4.98) \mathrm{A}$ & $1.19(1.67-2.36)$ \\
\hline High & 530 & 20 & $3.77(2.15-5.39) \mathrm{A}$ & $1.38(1.33-2.54)$ \\
\hline \multicolumn{5}{|c|}{ School holidays } \\
\hline No & 1437 & 30 & $2.08(1.34-2.82) \mathrm{A}^{\mathrm{a}}$ & - \\
\hline Yes & 423 & 23 & $5.43(3.33-7.59) \mathrm{B}$ & $2.61(1.53-4.44)$ \\
\hline
\end{tabular}

${ }^{a}=$ occurrence rates with different letters are statistically different from each other by the Tukey test at a $5 \%$ level of significance. ${ }^{b}=$ inference based on the price charged to customers by the establishment providing the service. 
NUNES, S.C.B.; MORONI, R.B.; MENDES, J.; JUSTINIANO, S.C.B. \& MORONI, F.T - Head lice in hair samples from youths, adults and the elderly in Manaus, Amazonas State, Brazil. Rev. Inst. Med. Trop. S. Paulo, 57(3): 239-44, 2015.

Table 3

Occurrence of head lice according to the hair characteristics of clients of barber shops and beauty parlors, in the city of Manaus, Amazonas State, Brazil

\begin{tabular}{|c|c|c|c|c|}
\hline & No. of samples examined & No. of samples positives & $\begin{array}{c}\text { Occurrence rate }(\%) \\
95 \% \text { confidence interval }\end{array}$ & $\begin{array}{l}\text { Prevalence ratio } \\
95 \% \text { confidence interval }\end{array}$ \\
\hline \multicolumn{5}{|l|}{ Hair length } \\
\hline Short & 378 & 11 & $2.91(1.22-4.60) \mathrm{A}$ & $1.62(0.68-3.88)$ \\
\hline Medium & 502 & 9 & $1.79(0.64-2.94) \mathrm{A}$ & - \\
\hline Long & 980 & 33 & $3.36(2.24-4.48) \mathrm{A}$ & $1.87(1.49-2.36)$ \\
\hline \multicolumn{5}{|l|}{ Type of hair } \\
\hline Curly & 164 & 6 & $3.65(0.78-6.52) \mathrm{A}$ & $2.06(0.76-5.59)$ \\
\hline Wavy & 564 & 10 & $1.77(0.69-2.85) \mathrm{A}$ & - \\
\hline Straight & 1132 & 37 & $3.26(2.23-4.29) \mathrm{A}$ & $1.84(1.29-2.62)$ \\
\hline \multicolumn{5}{|l|}{ Hair color } \\
\hline Dyed & 197 & 2 & $1.01(0-2.4) \mathrm{A}^{\mathrm{a}}$ & - \\
\hline Light & 122 & 3 & $2.45(0-5.19) \mathrm{B} . \mathrm{A}$ & $2.42(0.40-14.33)$ \\
\hline Dark & 1466 & 44 & $3.00(2.13-3.87) \mathrm{B} . \mathrm{A}$ & $2.97(0.72-12.09)$ \\
\hline Gray & 90 & 4 & $4.44(2.27-6.61)$ C. B & $4.39(1.06-18.09)$ \\
\hline \multicolumn{5}{|c|}{ Hair thickness } \\
\hline Thin & 1067 & 29 & $2.71(1.74-3.68) \mathrm{A}$ & - \\
\hline Thick & 793 & 24 & $3.02(1.83-4.21) \mathrm{A}$ & $1.14(0.68-1.92)$ \\
\hline
\end{tabular}

${ }^{a}=$ occurrence rates with different letters are statistically different from each other by the Tukey test at a $5 \%$ level of significance.

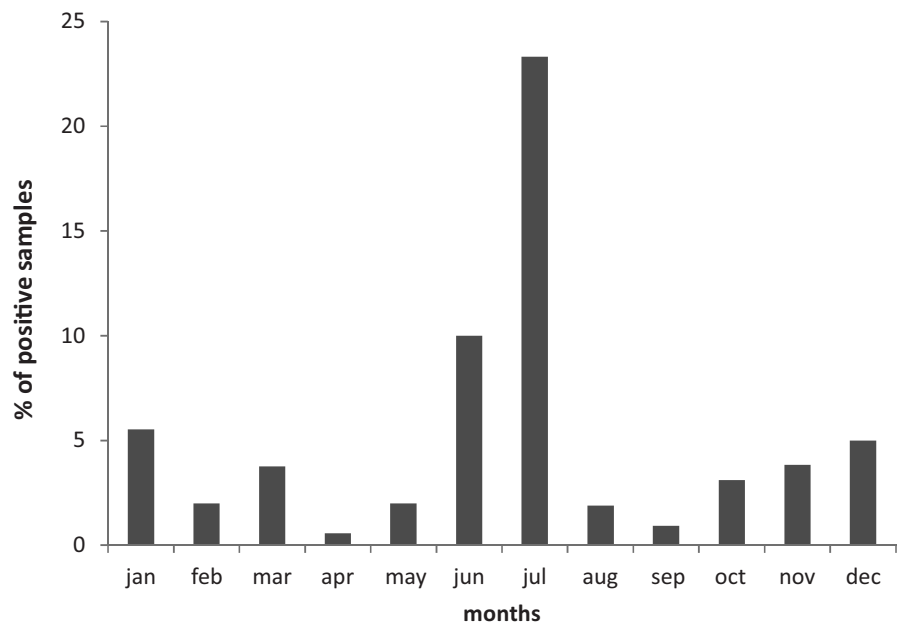

*Number of samples examined, $\mathrm{N}=1860$.

Fig. 1 - Monthly distribution of samples examined and samples positive for head lice, collected from 18 barber shops and beauty parlors, in Manaus, Amazonas State, Northern Brazil, from August 2010 to July 2013. School holiday period: Jan, Jun, Jul and Dec. Academic periods: Feb, Mar, Apr, May, Aug, Sep, Oct and Nov.

rates obtained for the different socioeconomic statuses, according to the price of a haircut charged by the establishment, seems to strengthen this hypothesis. Thus, procedures must be adopted to obtain more representative samples of this population group. One procedure adopted by BORGES et al. ${ }^{3}$ to sample this population group was the examination of samples of free haircuts during events promoted by charities and similar institutions in Uberlândia, MG. This should provide a clearer understanding of the real situation of this ectoparasitic disease in various age groups of the population group that are generally most affected ${ }^{12,21}$. Analysis of the monthly variations of infestation and comparison with the data obtained for schoolchildren in Manaus and other Brazilian cities $^{4,13}$ indicated that the profile of temporal variation of infestation in adults is different to the temporal variation in children. The profile of infestations in adults appears to be influenced by the difference in time spent together between these two age groups during the two periods of the year, the academic year and school vacations. Studies conducted in Brazil have shown that school-age children have the highest rates of head lice infestation ${ }^{2,13,20}$ and peak rates are observed in the months comprising the academic periods of the year ${ }^{4}$, when children spend a lot of the time in school and less time with the other members of their respective families. The greater interaction between children and their families during the vacations partially explains the increase in prevalence in other age groups during this period of the year.

Several authors mention the influence of temperature and humidity on the temporal profile of infestation ${ }^{13,22}$. The North and Northeastern regions of Brazil are subject to less annual variations in temperature. However, humidity has greater variation and is considered relatively low in some months, in which the lowest occurrence was observed. This result is consistent with findings reported by authors who also performed studies in the northeastern region ${ }^{13}$.

A higher occurrence rate among the elderly was also observed in Minas Gerais ${ }^{3}$. The data obtained herein, together with those just described, reinforce the hypothesis that the elderly are the second most 
NUNES, S.C.B.; MORONI, R.B.; MENDES, J.; JUSTINIANO, S.C.B. \& MORONI, F.T - Head lice in hair samples from youths, adults and the elderly in Manaus, Amazonas State, Brazil. Rev. Inst. Med. Trop. S. Paulo, 57(3): 239-44, 2015.

commonly affected age group in some cities. This is probably due, at least in part, to the following factors: they spend more time with children than other family members, and a number of the elderly are dependent on caregiver and live in or attend nursing homes or similar collective environments, under conditions conducive to the transmission of ectoparasitic diseases.

The higher occurrence among non-blacks verified in this study was also observed in American schools that attend a multiracial population of children ${ }^{14}$. In contrast, several studies have reported higher prevalence among black individuals ${ }^{2,4,6}$. These divergent reports could be related to several factors that have comparative influence on head lice infestation, such as different forms of hair among different ethnic groups, variations in cultural habits and different socioeconomic conditions ${ }^{5,17}$.

It should be emphasized that scalp examination is a more sensitive technique for diagnosing this parasitosis than the examination of cut hair samples. Thus, scalp examination should be used whenever possible. Despite their limitations, the diagnostic technique and sampling system adopted allowed for the accomplishment of the main objectives of the study, i.e. obtain information concerning the degree of importance of this ectoparasitic disease and the factors that most strongly influence the occurrence of head lice in the study population. However, additional procedures that would make the technique more sensitive while maintaining the ease of its application among the target population are required. Measures that improve sampling among the section of the population that finds it difficult or impossible to pay for a haircut would grant a more accurate view of the degree of importance of this ectoparasitic disease in the population group with low or no purchasing power, which is usually the group most affected by this parasitosis.

\section{RESUMO}

\section{Pediculose da cabeça em amostras de cabelos de jovens, adultos e idosos em Manaus, Estado do Amazonas, Brasil}

Estudo sobre a pediculose do couro cabeludo em jovens, adultos e idosos foi realizado de agosto de 2010 a julho de 2013 em Manaus - AM, região norte do Brasil. Amostras de cabelos obtidas de 1.860 indivíduos em 18 barbearias e salões de beleza foram examinadas à procura do parasito. Procurou-se verificar a ocorrência da pediculose e sua associação com fatores tais como: sexo, idade, etnia, características dos cabelos e perfil socioeconômico dos clientes dos salões, localização dos salões e variação sazonal. A taxa de ocorrência encontrada foi $2,84 \%$. Ela foi maior em amostras de cabelos de não negros e dos idosos. Também se observou maior prevalência no período de férias escolares do ensino fundamental e médio. Os resultados indicam que a ocorrência da pediculose em jovens, adultos e idosos em Manaus é relativamente baixa em comparação com as encontradas em crianças e as encontradas em outras regiões do país. Depois das crianças, os idosos seriam os mais acometidos. O estudo também indica a necessidade de adotar procedimentos adicionais para melhor amostrar a faixa da população com menor ou com nenhum poder aquisitivo, a qual geralmente é a mais acometida por esta ectoparasitose.

\section{ACKNOWLEDGMENTS}

The authors would like to thank the establishments involved in this work and the National Council of Scientific and Technological Development (CNPq) and the Amazon Research Foundation (FAPEAM) for providing study grants.

\section{FINANCIAL SUPPORT}

The National Council of Scientific and Technological Development (CNPq/MCT-Amazônia 2006/2008) provided support for this study.

\section{CONFLICTS OF INTEREST}

The authors declare that there are no conflicts of interest.

\section{REFERENCES}

1. Bechelli LM, Haddad N, Pimenta WP, Pagnano PMG, Melchior JE, Fregnan RC, et al. Epidemiological survey of skin diseases in schoolchildren living in the Purus Valley (Acre State, Amazonia, Brazil). Dermatologica. 1981;163:78-93.

2. Borges R, Mendes J. Epidemiological aspects of head lice in children attending day care centers, urban and rural schools in Uberlândia, Central Brazil. Mem Inst Oswaldo Cruz. 2002;97:189-92.

3. Borges R, Silva JJ, Rodrigues RM, Mendes J. Prevalence and monthly distribution of head lice using two diagnostic procedures in several age groups in Uberlândia, State of Minas Gerais, Southeastern Brazil. Rev Soc Bras Med Trop. 2007;40:247-9.

4. Borges-Moroni R, Mendes J, Justiniano SCB, Bindá AGL. Pediculose do couro cabeludo em crianças de creches e escolas de Manaus, Amazonas, Brasil. Rev Patol Trop. 2011;40:263-70

5. Brenner LR. How to control lice. Nurs Care. 1977;10:20-2.

6. Carzola D, Ruiz A, Acosta M. Estudio clínico-epidemiológico sobre Pediculosis capitis en escolares de Coro, estado Falcón, Venezuela. Invest Clin. 2007;48:445-57.

7. Castro DC, Abrahamovich AH, Cicichino AC, Rigoni AM, Raffaeli C, de Barrio A Prevalencia y estacionalidad de la Pediculosis capitis en la población infante-juvenil de la región sanitaria, Buenos Aires, Argentina. Rev Saude Publica. 1994;28:295-9.

8. Catalá S, Carrizo L, Córdoba M, Khairallah R, Moschella F, Bocca JN, et al. Prevalência e intensidade da infestação por Pediculus humanus capitis em escolares de seis a onze anos. Rev Soc Bras Med Trop. 2004;37:499-501.

9. Catalá S, Junco L, Vaporaky R. Pediculus capitis infestation according to sex and social factors in Argentina. Rev Saude Publica. 2005;39:438-43.

10. Donaldson RJ. The head louse in England: prevalence amongst schoolchildren. R Soc Health J. 1976;96:55-7.

11. Falagas ME, Matthaiou DK, Rafailidis PI, Panos G, Pappas G. Worldwide prevalence of head lice. Emerg Infect Dis. 2008;14:1493-4.

12. Feldmeier H, Heukelbach J. Epidermal parasitic skin diseases: a neglected category of poverty-associated plagues. Bull World Health Organ. 2009;87:152-9.

13. Heukelbach J, Wilcket T, Winter B, Feldmeier H. Epidemiology and morbidity of scabies and pediculosis capitis in resource-poor communities in Brazil. Br J Dermatol. $2005 ; 153: 150-6$

14. Hoffmann G. Epidemiology and control of pediculosis capitis infestation in the Federal Republic of Germany. J R Soc Health. 1983;103:88-92.

15. Instituto Brasileiro de Geografia e Estatística (IBGE). Updated 2013 January 2010. Rio de Janeiro: IBGE; 2013. [cited 2013 Oct 29]. Available from: http://www.ibge gov.br 
NUNES, S.C.B.; MORONI, R.B.; MENDES, J.; JUSTINIANO, S.C.B. \& MORONI, F.T - Head lice in hair samples from youths, adults and the elderly in Manaus, Amazonas State, Brazil. Rev. Inst. Med. Trop. S. Paulo, 57(3): 239-44, 2015.

16. Jahnke C, Bauer E, Hengge UR, Feldemeier H. Accuracy of diagnosis of pediculosis capitis: visual inspection vs wet combing. Arch Dermatol. 2009;145:309-13.

17. Linardi PM, Botelho JR, Maria M, Cunha HC. Crendices e falsos conceitos que dificultam ações profiláticas contra o piolho e a pediculose. J Pediatr. 1988a;64:24855.

18. Linardi PM, Maria M, Botelho JR, Cunha HC, Ferreira JB. Prevalence of nits and lice in samples of cut hair from floors of barbershops and beauty parlors in Belo Horizonte, Minas Gerais State, Brazil. Mem Inst Oswaldo Cruz. 1988b;83:471-4.

19. Linardi PM, De Maria M, Botelho JR, Cunha HC, Ferreira JB. Pediculose capitis: prevalência em escolares da rede municipal pública de Belo Horizonte, Minas Gerais, Brasil. Mem Inst Oswaldo Cruz. 1989;84:327-31.

20. Linardi PM, De Maria M, Botelho JR, Hosken CI, Cunha HC. Alguns fatores epidemiológicos relativos à infestação humana por Pediculus capitis (ANOPLURA, PEDICULIDAE) em Belo Horizonte, Minas Gerais, Brasil. Rev Bras Entomol. 1995;39:921-9.

21. Manrique-Saide P, Pavía-Ruz N, Rodriguez-Buenfil JC, Herrera Herrera R, GomézRuiz P, Pilger D. Prevalence of pediculosis capitis in children from a rural school in Yucatan, Mexico. Rev Inst Med Trop Sao Paulo. 2011;53:325-7.

22. Mimouni D, Ankol OE, Gdalevich M, Groto I, Davidovitch N, Zangvil E. Seasonality trends of Pediculosis capitis and Phthirus pubis in a young adult population: followup of 20 years. J Eur Acad Dermatol Venereol. 2002;16:257-9.
23. Mirza A, Shamsi A. Head lice infestation. Innovait. 2010;3:85-90.

24. Moradi AR, Zahirnia AH, Alipour AM, Eskandari Z. The prevalence of pediculosis capitis in primary school students in Bahar, Hamadan Province, Iran. J Res Health Sci. 2009;9:45-9

25. Motovali-Emami M, Aflatoonia MR, Fekri A, Yazdi ME. Epidemiological aspects of pediculosis capitis and treatment evaluation in primary-school children in Iran. Pak J Biol Sci. 2008;11:260-4.

26. Oh J, Lee IY, Lee WJ, Seo M, Park SA, Lee SH, et al. Prevalence of pediculosis capitis among Korean children. Parasitol Res. 2010;107:1415-9.

27. Toloza A, Vassena C, Gallardo A, González-Audino P, Picollo MI. Epidemiology of Pediculosis capitis in elementary schools of Buenos Aires, Argentina. Parasitol Res. 2009;104:1295-8.

28. Vladeni S, Petinaki E, Roussaki-Schultze A. Hair characteristics and lice infestation Data from schoolchildren in Greece. J Eur Acad Dermatol Venereol. 2011;25:118-9.

29. Zar JF. Biostatistical analysis. New Jersey: Prentice Hall; 1999.

30. World Health Organization. Young people's health: a challenge for society. Report of a WHO Study Group on Young People and "Health for All by the Year 2000". Geneva: WHO; 1986. (Technical Report Series 731).

Received: 15 January 2014

Accepted: 30 July 2014 